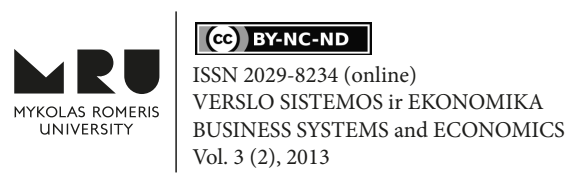

\title{
DETERMINANTS OF THE PROPERTY ASSESSMENT UNIFORMITY
}

\author{
Liucija BIRŠKYTÉ \\ Mykolas Romeris University, \\ Ateities str. 20, LT-08303 Vilnius, Lithuania \\ E-mail: lbirskyte@mruni.eu
}

doi:10.13165/VSE-13-3-2-04

\begin{abstract}
As Lithuania ponders the adoption of the universal property tax on real estate, the advantages and disadvantages of property taxation are discussed in media and scholarly articles. At the heart of the property tax, there is the need for assessment, the determination of property value for taxation purposes. The importance of assessment for the equitable distribution of the total tax burden does not receive enough emphasis in research. This article attempts to fill in this gap by testing an empirical model based on the data from the USA, a country, where property taxation has a long history. The model tests what factors are contributing to the variation of the coefficient of dispersion (COD), an internationally recognized measure of assessment uniformity. The results of the analysis indicate that the economic structure and housing market conditions are the most important determinants of the property assessment uniformity, while variables related to the location of property and the level of taxation do not have a significant impact on assessment uniformity.
\end{abstract}

Key words: real estate, property tax, vertical inequity, horizontal inequity, assessment. JEL classification: $\mathrm{H} 21$, H71.

\section{Introduction}

Amendments made to the Law of Immovable Property Tax effective since January, 2012 have ignited a public debate about the pros and cons of levying a property tax on all residential real property, i.e. making the tax universal ("Law on Immovable Property Tax of the Republic of Lithuania", 2005). Though the mechanism of the property taxation is well known, some of its elements, such as the need to estimate the tax base, i.e. make assessments, are unique to the property tax. Assessment is at the heart of real property taxation. In contrast to other taxes, it is not a tax on the flows of income or on a transaction. It is a tax on stock value, which must be estimated, at one point in time. The most widely used benchmark for property assessment is market value. However, the real market value gets revealed only through a sales transaction. Assessors have to determine the hypothetical exchange value. Quite often, the assessment is identified as biased and at- 
tacked for the inequities it creates. Some properties may be systematically under-appraised or over-appraised, creating vertical inequity. Horizontal inequities occur, when persons possessing similar properties in terms of their value pay different taxes due to different assessment ratios.

Due to the crucial importance of uniform assessment for equitable taxation, assessment standards have been developed by the International Association of Assessing Officers (IAAO). Assessment standards are based on assessment ratios studies. Assessment ratio is a ratio of the market value to the assessed value. The closer the assessed value hits the market value, the better the tax payment matches the capability to pay the tax. Another objective statistic, which is the coefficient of dispersion (COD), has been designed to measure assessment uniformity. Uniformity relates to the consistency of assessment levels within property groups. The COD is the average absolute deviation of the calculated sale ratios from their median, expressed as a percentage of the median (International Association of Assessing Officers, 2013). Larger COD values indicate diminished uniformity. The COD is a measure of horizontal equity (Moore, 2007).

The author of this paper attempts to find which factors have an effect on the assessment uniformity. Based on previous research, an empirical model has been built to test which variables related to economic structure, assessment environment, assessment system and property tax system contribute to the variation in the COD. The analysis uses crosssectional data from sales disclosures data on the counties in the state of Indiana, USA.

The paper is organized in the following way: in section two, the literature review on property taxes and assessment problems is presented. It reveals the advantages and disadvantages of real property taxation and reviews previous research on assessment uniformity. The third section is devoted to the description of the empirical model used in the paper and discusses the results of regression analysis. Finally, the last section presents the conclusions of the study.

\section{Literature Review}

\section{Pros and Cons of Property Taxation}

Property taxes of various designs are adopted by governments throughout the world. According to the International Association of Assessing Officers (IAAO), different versions of property taxes exist in about 130 countries (International Association of Assessing Officers, 2012). Local governments of the United States of America and Canada rely heavily on property tax revenue. In 2009, property taxes accounted for 73.9 percent of the total local government tax revenue in the U.S.(U.S. Census Bureau, 2009).

There are no other broad-based revenue options that are as well suited for local use as is this tax; the base is immobile, revenue from this tax is stable during the recession, the rate can vary within small geographical areas to support even the smallest local government (Mikesell, 2013; Ter-Minassian, 1997). In addition to being crucial for fiscal independence of local governments, property taxes are recommended by tax experts for their efficiency, equity and transparency (Mikesell, 2013; Oates, 1999). The real property tax meets the "benefits received" principle of taxation. The revenue collected will be mostly used to finance local services that benefit a local population, such as fire protection and high quality local schools. In this view, property taxes resemble prices for services provided by the local 
government. The tax applies to owners of property, including extremely valuable property, and, therefore, meets "the ability to pay principle" and may add to the progressivity of the tax system as a whole. Property taxes are visible. Citizens have an incentive to get involved in the decision-making process of the local government, including the demand of greater accountability in fiscal affairs. This contributes to a greater alignment of citizen preferences and the provision of public goods and services (Martinez-Vasquez, 1994).

In spite of their contribution to the integrated taxation systems, the property tax is often called "the worst tax" (Fisher, 1996). Public dissatisfaction with the tax can be attributed to its high visibility (paid annually or semi-annually in one lump sum), inequitable administration and redistribution of the tax burden from commercial to residential property, as market values increased more quickly in homes (Brunori, 2003).

Property taxes often create horizontal inequity, as effective rates vary substantially across properties of similar value due to the lack of uniformity in assessment ratios. Local property taxes may contribute to fiscal disparity between localities, as some localities are rich in valuable property and others are not. Property tax burdens can become shockingly high for people living in areas with increasing property values and can become difficult for people with low income. As income decreases with age, the high property tax bill may disproportionally and unfairly affect older people, who have worked hard to become the owners of a house. The property tax can have a negative impact on the economic development by reducing the after-tax return from building upgrading productive facilities (Mikesell, 2013).

\section{Property Assessment and Equity in Taxation}

The hardest part about the practice of the property taxation is the need to assess the property. In contrast to other taxes, it is not a tax on the flows of income or on a transaction. It is a tax on stock value at one point in time. This value must be estimated. This estimation or assessment - determines what tax value is ascribed to each property and, by aggregation, the total tax value to the government. Therefore, the assessment of the tax base is the critical stage of administration. Quite often, the assessment is identified as biased and attacked for the inequities it creates.

Assessment bias occurs due to the lack of assessment uniformity. Assessment uniformity is related to the fair and equitable treatment of individual properties. Each property (each real estate parcel) has to be assessed at the same level, or ratio, of market value. The standards recommended by the IAAO stipulate that the median ratio should be between 0.90 and 1.10 (International Association of Assessing Officers, 2013). This standard means that the assessed value has to be as close to the market value, i.e. as revealed during the sales transaction, as possible. If some classes of property have a ratio of the assessed value to the market value significantly different from the ratios for other classes of property in the same jurisdiction, assessment inequities occur (Birch, Sunderman \& Smith, 2004). Inequity can be horizontal or vertical. Horizontal inequities refer to the systematic differences in the assessment level, when persons possessing similar properties in terms of their value pay different taxes due to different assessment ratios. Vertical inequity occurs, when different value properties are systematically under-appraised or over-appraised. Vertical inequity is regressive, when high-value properties are under-appraised and are relative to low-value properties. If the opposite is true, inequity is progressive. 


\section{Measures of assessment uniformity}

Horizontal inequities are measured by the coefficient of dispersion (COD). The coefficient of dispersion equals the average absolute deviation of parcel assessment ratios from the median assessment ratio divided by the median and multiplied by 100 (Mikesell, 2013, p. 511).

where:

$$
C O D \cong\left[\frac{\sum_{i=1}^{n}\left(A_{i}-M\right)}{n}\right]\left[\frac{1}{M}\right][x 100],
$$

$A_{i}=$ assessment ratio for an individual property parcel,

$M=$ median assessment ratio for all parcels sampled, and

$N=$ number of parcels in the sample.

If assessment ratios of individual properties are clustered closely around the median ratio, the COD will be low, and it can be concluded that the assessments are relatively uniform. If individual ratios vary widely around the median, the COD will be high, and it implies that properties are not uniformly assessed and the property burden is not fairly distributed among the taxpayers (Mikesell, 2013, p. 511). The IAAO recommends the following standards for the COD (International Association of Assessing Officers, 2013):

- Single-family homes and condominiums: CODs of 5 to 10 for newer or fairly similar residences and 5 to 15 for older or more heterogeneous areas;

- Income-producing properties: CODs of 5 to 15 in larger, urban areas and 5 to 20 in other areas;

- Vacant land: CODs of 5 to 20 in urban areas and 5 to 25 in rural or seasonal recreation areas;

- Rural residential, seasonal and manufactured homes: CODs of 5 to 20.

Several empirical studies have been done on the uniformity of assessment. Using cross-sectional data for Virginia counties and independent cities, Bowman and Mikesell found evidence that local assessors' own staffs were less effective in providing assessment uniformity than were private or state contract appraisal firms (Bowman \& Mikesell, 1978). In another research, they built a model to examine differences in the uniformity of market value assessments for agricultural real property, in which the COD was regressed on the number of explanatory variables representing economic/agricultural structures and the property tax system (Bowman \& Mikesell, 1988). The chosen variables accounted for 58 percent variation in the market value assessment uniformity. Since in some jurisdictions assessors can be either locally elected or appointed by the local governments, Bowman and Mikesell tested whether assessment uniformity depends upon the assessor selection process (Bowman \& Mikesell, 1989). The results were not statistically significant and failed to establish the relationship between the assessment uniformity and the fact if assessors were appointed or elected. In a more recent study, Birch, Sunderman and Smith found evidence of significant vertical inequity in property taxes using a set of residential sales from Bloomington, Indiana (Birch et al., 2004).

It is important to achieve assessment uniformity if the goal of the tax system is equitable treatment of all taxpayers. This characteristic of the tax system is relevant because of the 
need to maintain taxpayer's confidence in the fairness of taxation. Assessment inequities can cause taxpayers to lose confidence in the system, lead to tax revolts and ultimately erode the tax base (Thompson \& Green, 2004; Wallin, 2004).

\section{Methodology}

In this paper, the determinants of the coefficient of dispersion (COD) are tested empirically. First, using the cross-sectional data for Indiana counties, the COD is calculated using Formula 1 above. Description of data and data sources are provided in Annex 1. Second, the model is built to identify the effects of the property tax system, the assessor's qualifications and the environment, in which the assessment takes place on the observed assessment quality, as measured by the COD. The model can be stated as:

$\ln \mathrm{COD}_{\mathrm{i}}=\beta_{1}+\beta_{2} \mathrm{AGR}_{\mathrm{i} 2}+\beta_{3} \mathrm{VAL}_{\mathrm{i} 3}+\beta_{4} \mathrm{DUNT}_{\mathrm{i} 4}+\beta_{5} \mathrm{DETER}_{\mathrm{i} 5}+\beta_{6} \mathrm{VAC}_{\mathrm{i} 6}+\beta_{7} \mathrm{LVAL}_{\mathrm{i} 7}+$ $\beta_{8} \mathrm{LOC}_{\mathrm{i} 8}+\beta_{9} \mathrm{MSA}_{\mathrm{i} 9}+\beta_{10} \mathrm{EFTR}_{\mathrm{i} 10}+\varepsilon_{\mathrm{i}}$

where:

In COD is the natural logarithm of the index of assessment uniformity;

AGR is the percentage of land area in agricultural use;

VAL is the median housing value;

DUNT is the change in housing units;

DETER is the percentage of housing units with more than 1.0 persons per room;

LVAL is the percentage of home units with market value below $\$ 50,000$;

$\mathrm{VAC}$ is the percentage of year round vacant housing units;

LOC is a dummy variable, which takes the value of 1 if assessment is carried out by local assessors and the value of 0 if it is carried out by professional (contracted) assessors;

MSA is a dummy variable, which takes the value of 1 if the county is located in a metropolitan statistical area and the value of 0 if otherwise;

EFTR is an effective property tax rate;

$\varepsilon_{\mathrm{i}}$ is a random error term.

\section{Discussion of Variables}

The dependent variable is the natural logarithm of the coefficient of dispersion for properties sold in 1999. The previous studies have demonstrated that logarithmic formulation is superior to the arithmetic COD as a measure of performance (Bowman \& Mikesell, 1978).

Explanatory variables can be roughly divided into three categories: variables representing economic structure and assessment environment (AGR, VAL, DUNT, DETER, LVAL, VAC, MSA), assessment system (LOC) and property tax system (EFTR). AGR, the percent of land in agricultural use, is expected to have a negative sign, because theory suggests that a larger portion of area devoted to agricultural use implies a less complex and homogeneous economic structure, which would make assessment easier and more uniform (Bowman \& Mikesell, 1988). VAL, the housing value, is expected to have a negative sign, because as the value of the housing increases, the assessors may assert greater vigilance and the assessment accuracy should increase. DUNT, the change in housing units, represents the housing market. A negative relationship is expected because the greater change in housing units means more new constructions. New homes are likely to be assessed more accurately than the old 
ones because the costs of construction are rather uniform and known. Also, the depreciation, a subjective factor, does not enter the calculus of assessment to the degree, to which the assessment of old homes does. DETER, the number of housing units with more than one person per room, is a proxy for deterioration or low-quality housing. There is some evidence that assessors often fail to mark down the assessed value as property deteriorates (Bowman \& Mikesell, 1978). Since deterioration is an opposite of new construction (DUNT), a positive relationship is expected. Assessment of deteriorated properties is more difficult and, therefore, less uniform. LVAL, the percentage of low value properties, is a proxy of property tax relief. It is often assumed that assessors try to relieve the tax burden for low-income and elderly property owners (ibid.) Taking into consideration the condition of the property, a tax assessor would judge on the financial situation of the owner and may be induced to assess it at a lower value, granting an illegal tax relief. Such practices introduce irregularities in tax assessment and, therefore, the expected sign is positive.

VAC, a vacancy rate, represents a housing market disequilibrium (over-supply). Theory suggests that market values will decline, but assessors may be unwilling to reduce the assessed values. Therefore, this variable is expected to have a positive sign, indicating more complex assessing environment and subsequent higher coefficients of dispersion.

MSA (metropolitan statistical area) is a variable created to test whether there are differences between assessment quality in urban areas and rural areas. A negative sign is expected because urban areas have a more active real property market. Since the current market values convey useful information to assessors, the assessment uniformity is likely to increase.

LOC represents the assessment system. In some localities, assessments are made by local assessors, whereas in others, assessments are done by contracted professional assessors. The expected sign for this variable is not clear because there are two competing theories: one of them states that the outside contractors have a greater expertise and develop better skills. These assessor qualities would ensure a better assessment quality than that achieved by the local assessors. In this case, the expected sign for LOC would be positive. However, there is a contradicting view, asserting that the local assessors are more knowledgeable of local conditions (Bowman \& Mikesell, 1989). Therefore, their assessment results would be superior to those produced by the contracted outside assessors. In this case, the sign would be negative.

The last variable, EFTR - an effective tax rate - measures the property tax burden. As the amount of tax paid increases relatively to the market value, the property owners will be more likely concerned that the assessment is fair. They will be more likely to monitor the assessment quality through the appeal process, which should induce a more accurate assessment process. For this reason, higher effective rates should improve the assessment quality, i.e. lower COD. 
Table 1. Regression results for the determinants of the assessment uniformity. Dependent variable - coefficient of dispersion (COD)

\begin{tabular}{|c|c|c|}
\hline $\begin{array}{c}\text { Variables } \\
\text { (Expected Sign) } \\
\end{array}$ & $\begin{array}{c}\text { Coefficient } \\
\text { (Standard Error) }\end{array}$ & P-value \\
\hline $\begin{array}{l}\text { AGR } \\
(-)\end{array}$ & $\begin{array}{l}-0.0523 \\
(0.1502) \\
\end{array}$ & 0.7285 \\
\hline $\begin{array}{l}\text { VAL } \\
(-)\end{array}$ & $\begin{array}{c}-0.00002^{* * *} \\
(0.000006)\end{array}$ & 0.0083 \\
\hline $\begin{array}{l}\text { DUNT } \\
(-)\end{array}$ & $\begin{array}{l}-1.013^{* *} \\
(0.4845) \\
\end{array}$ & 0.0397 \\
\hline $\begin{array}{l}\text { DETER } \\
(+)\end{array}$ & $\begin{array}{l}8.4599^{* *} \\
(3.7431)\end{array}$ & 0.0265 \\
\hline $\begin{array}{l}\text { VAC } \\
(+) \\
\end{array}$ & $\begin{array}{c}6.6249^{* * *} \\
(1.3456) \\
\end{array}$ & 0.0001 \\
\hline $\begin{array}{l}\text { LVAL } \\
(+)\end{array}$ & $\begin{array}{l}-0.0944 \\
(0.7243)\end{array}$ & 0.8966 \\
\hline $\begin{array}{l}\mathrm{LOC} \\
(?)\end{array}$ & $\begin{array}{l}-0.0560 \\
(0.0477) \\
\end{array}$ & 0.2436 \\
\hline $\begin{array}{l}\text { MSA } \\
(-)\end{array}$ & $\begin{array}{l}-0.0479 \\
(0.0605) \\
\end{array}$ & 0.4308 \\
\hline $\begin{array}{l}\text { EFTR } \\
(-)\end{array}$ & $\begin{array}{c}0.2889 \\
(0.9436)\end{array}$ & 0.7603 \\
\hline
\end{tabular}

Adj $\mathrm{R}^{2} \quad 0.7052$

F-value 24.92

$\mathrm{N}=92$

Note: ${ }^{* *}$ significant at 0.01 level; ${ }^{* *}$ significant at 0.05 level; ${ }^{*}$ significant at 0.1 level (two-tailed tests). Source: author's calculations

The model was estimated using proc reg procedure of SAS program. Regression results are summarized in Table 1. Estimated results roughly conform to those, which were predicted. Out of nine explanatory variables, all took the expected signs, except for two variables: LVAL and EFTR. Two variables (VAL and VAC) are significant at 0.01 percent level or higher. Two variables (DUNT, DETER) are significant at 0.05 percent level. The rest five variables are not statistically significant. The coefficient of determination $\mathrm{R}^{2}$ of 0.7052 indicates that the model explains about 71 percent of the variation in the dependent variable (COD). Most of the predictive power of the model can be attributed to economic structure variables. The variables representing the assessment system and the tax burden are not statistically significant, though the LOC and the MSA have the signs predicted by the theory.

The test for the multicollinearity (VIF or variance inflation test) detects a rather strong collinearity between the VAL and the LVAL variables. Collinearity indicates that these two variables move together in a systematic way and their individual effects cannot be isolated. This leads to imprecise parameter estimates (Gujarati, 2006). This might also be the reason why the variable representing low value is statistically insignificant. Restricting the model., i.e. leaving the LVAL variable out, dramatically increases the significance of the variable VAL. It becomes significant at a less than .0001 level and the VIF decreases from 8.51 to 3.12. The change in the predictive power of the restricted model as measured by the $\mathrm{R}^{2}$ and the Adj $\mathrm{R}^{2}$ (which accounts for the number of the variables in the model) is negligible, while 
the F-value increases from 24.92 to 28.37 , indicating that the overall significance does not decrease with the restriction.

Other two insignificant variables AGR and EFTR are retained in the model due to the prominence of these variables in the theory. The insignificance of the EFTR may be explained by the lack of variation in the values of this explanatory variable within the sample data. This problem can be viewed in the context of the collinearity because when an explanatory variable offers little variation, it is difficult to detect or isolate the effect of the variable within the model.

Two dummy variables, though of the expected signs, are not statistically significant. The t-test of the variable LOC does not support the hypothesis that the choice of assessors, whether local or professional, is related to the assessment quality. Similarly, the fact that a county is situated in the MSA or outside the MSA does not have a significant impact on the size of the coefficient of dispersion, though the median COD (0.26) for the counties located in the MSA is lower than the median COD (0.36) for the counties outside the MSA.

Another threat to the validity of the results is heteroskesdasticity, which refers to the assumption that the error term has constant variance. This assumption is often violated in cross-sectional data sets (Studenmund, 1997). However, the White's test does not indicate heteroskedasticity problems in the model ( $\mathrm{Pr}>\mathrm{ChiSq}$ is 0.5856$)$. Though the data is crosssectional, most of the variables are standardized rendering the heteroscedasticity unlikely.

\section{Conclusion}

The results of the model estimation strongly support the importance of economic structure and housing market conditions on assessment uniformity. The increase in median housing value and the new construction contribute to a better assessment quality. On the contrary, the deterioration of housing and the market disequilibrium (over-supply) has a negative effect on the assessment uniformity. However, these factors are out of the range of influence of the policy makers responsible for ensuring greater horizontal equity in property taxation. This analysis does not support the hypothesis that the way an assessor is appointed, through elections or on merit basis, has an impact on the assessment uniformity. Though counties located within urban areas on average manifest greater assessment uniformity, as measured by the coefficient of dispersion, the effect is statistically insignificant, when other factors are included in the regression model. Better measures and more refined models are needed to capture the effects of policy variables as well as other possible determinants of the assessment quality. 


\section{References}

1990 Census of Population and Housing. Retrieved April 15, 2002 from http://govinfo.library.orst.edu

Birch, J., Sunderman, M., \& Smith, B. (2004). Vertical inequity in property taxation: A neighborhood based analysis. The Journal of Real Estate Finance and Economics, 29(1): 71-78.

Bowman, J. H., \& Mikesell, J. L. (1978). Uniform asseessment of property: Returns from institutional remedies. National Tax Journal, 31: 137-153.

Bowman, J. H., \& Mikesell, J. L. (1988). Assessment of agricultural property for taxation. Land Economics, (64): 28-35.

Bowman, J. H., \& Mikesell, J. L. (1989). Elected versus appointed assessors and the achievement of assessment uniformity. National Tax Journal, 42(2): 181-189.

Brunori, D. (2003). Local tax policy: A federalist perspective. Washington, DC: Urban Institute.

Bureau of Labor Statistics. (2002). Economy at a glance. Retrieved March 30, 2002 from http://www. bls.gov/eag

Census of Agriculture. (1997). Farm land. Retrieved April 15, 2002 from http://www.fedstats.gov/ key_stats/

Fisher, G. W. (1996). The worst tax? A history of property tax in America. Kansas: University Press of Kansas.

Gujarati, D. N. (2006). Essentials of econometrics (3rd ed.). New York: McGraw-Hill.

Indiana Department of Local Government Finance. (2002). Taxbook: Levy. Retrieved April 12, 2002 from http://www.in.gov/dlgf/pubs/taxbook/levy/table29.html

International Association of Assessing Officers. (2012). Retrieved August 30, 2013 from http://www. iaao.org/library/

International Association of Assessing Officers. (2013). Standard on mass appraisal of real property. Retrieved August 30, 2013 from http://www.iaao.org/sitePages.cfm?Page=219

Law on Immovable Property Tax of the Republic of Lithuania, No. X-233, Lithuanian Parliament, June 7, 2005 Sess. (2005).

Martinez-Vasquez, J. (1994). Expenditures and expenditure assignment. In C. I. Wallich (ed.), Russia and the challenge of fiscal Federalism (99). Washington, D.C.: World Bank.

Mikesell, J. (2013). Fiscal administration: Analysis and appplications for the public sector (9th ed.). Boston: Wadsworth.

Moore, W. J. (2007). Property tax equity implications of assessment capping and homestead exemptions for owner-occupied single-family housing. Journal of Property Tax Assessment \& Administration, 5(37).

Oates, W. E. (1999). An essay on fiscal federalism. Journal of Economic Literature, 37: 1120-1149.

Studenmund, A. H. (1997). Using econometrics: A practical guide (3rd ed.). Reading, Ma: AddisonWesley.

Ter-Minassian, T. (ed.). (1997). Intergovernmental fiscal relations in a macroeconomic perspective. Washington: International Monetary Fund.

Thompson, F., \& Green, M. T. (2004). Vox populi? Oregon tax and expenditure limitation initiatives. Public Budgeting \& Finance, 24(4): 73-87.

U.S. Census Bureau. (2009). Annual survey of state and local government. Retrieved August 30, 2013 from www.census.gov

U.S. Census Bureau. (2000). STATS Indiana profiles. Retrieved April 15, 2002 from http://www.stats. indiana.edu/profiles/

Wallin, B. A. (2004). The tax revolt in Massachusetts: Revolution and reason. Public Budgeting \& Finance, 24(4): 34-50. 


\title{
Appendix 1
}

\section{Data Description and Sources}

\begin{tabular}{|c|c|c|}
\hline Symbol & Definition & Source \\
\hline COD & $\begin{array}{l}\text { Natural log of the coefficient of dispersion calculated } \\
\text { from sales disclosure data for all Indiana counties for } \\
\text { the year } 1999\end{array}$ & $\begin{array}{l}\text { Data supplied by Indiana Dept. } \\
\text { of Local Government Finance }\end{array}$ \\
\hline AGR & The percentage of land area in agricultural use, 1997 & Census of Agriculture, 1997 \\
\hline VAL & Median housing value of owner-occupied in 1990 & $\begin{array}{l}1990 \text { Census of Population and } \\
\text { Housing }\end{array}$ \\
\hline DUNT & $\begin{array}{l}\text { The percentage change in housing units from } 1990 \text { to } \\
2000\end{array}$ & $\begin{array}{l}1990 \text { Census of Population and } \\
\text { Housing; U.S. Census Bureau, } \\
2000\end{array}$ \\
\hline DETER & $\begin{array}{l}\text { The percentage of housing units with more than } 1.0 \\
\text { persons per room, } 1990\end{array}$ & $\begin{array}{l}1990 \text { Census of Population and } \\
\text { Housing }\end{array}$ \\
\hline LVAL & $\begin{array}{l}\text { The percentage of home units with the market value } \\
\text { below } \$ 50,000 ; 1990\end{array}$ & $\begin{array}{l}1990 \text { Census of Population and } \\
\text { Housing }\end{array}$ \\
\hline VAC & The percentage of year round vacant housing units, 1990 & $\begin{array}{l}1990 \text { Census of Population and } \\
\text { Housing }\end{array}$ \\
\hline LOC & $\begin{array}{l}\text { A dummy variable, which takes the value of } 1 \text { if assess- } \\
\text { ment is carried out by local assessors and the value of } 0 \\
\text { if it is carried out by professional (hired) assessors. The } \\
\text { most recent assessment year is } 1995 \text {. }\end{array}$ & $\begin{array}{l}\text { Unpublished data supplied by } \\
\text { Brian Booker, Indiana Dep. of } \\
\text { Local Gov. Finance (2002) }\end{array}$ \\
\hline MSA & $\begin{array}{l}\text { A dummy variable, which takes the value of } 1 \text { if the } \\
\text { county is located in a metropolitan statistical area and } \\
\text { the value of } 0 \text { if otherwise. }\end{array}$ & Bureau of Labor Statistics, 2002 \\
\hline EFTR & Effective property tax rate (\%) & $\begin{array}{l}\text { Indiana Department of Local } \\
\text { Government Finance, } 2002\end{array}$ \\
\hline
\end{tabular}

\section{FAKTORIAI, NUO KURIŲ PRIKLAUSO TURTO VERTINIMO TOLYGUMAS}

\author{
Liucija BIRŠKYTE் \\ Mykolo Romerio universitetas, Lietuva
}

Santrauka. Svarstant ịvesti visuotinị nekilnojamojo turto mokestį Lietuvoje, žiniasklaidoje ir mokslineje literatūroje diskutuojami turto apmokestinimo privalumai ir trūkumai. Nekilnojamojo turto mokesčio instrumentarijaus pagrindinis elementas yra turto vertinimas, jo vertės nustatymas apmokestinimo tikslu. Turto įvertinimo svarba teisingam mokesčio naštos paskirtymui nèra pakankamai akcentuojama moksliniuose tyrimuose. Šio straipsnio tikslas yra užpildyti šią spragą sukuriant ir ịvertinant empirinị modelį remiantis Jungtinių Amerikos Valstijų, kuriose turto mokestis yra svarbiausias vietinių biudžetų pajamų šaltinis ir turi ilgą istoriją, duomenimis. Modeliu bandoma nustatyti faktorius, kurie nulemia dispersijos koeficiento dydį. Dispersijos koeficientas yra tarptautiniu mastu pripažintas įvertinimo tolygumo rodiklis. Regresinès analizès rezultatai rodo, kad ekonomikos struktūra ir nekilnojamojo turto rinkos sąlygos yra svarbiausi faktoriai, nuo kurių priklauso turto vertinimo tolygumas, o kintamieji susiję su turto buvimo vieta ir mokesčio dydis neturi statistiškai reikšmingo poveikio vertinimo tolygumui.

Reikšminiai žodžiai: nekilnojamojo turto mokestis, vertikali nelygybė, horizontali nelygybė, turto vertinimas, dispersijos koeficientas. 